\title{
PENGARUH MODEL PEMBELAJARAN INQUIRY TRAINING TERHADAP HASIL BELAJAR SISWA PADA MATERI POKOK LISTRIK DINAMIS
}

\author{
Desri S Sipapaga dan Ida Wahyuni \\ Jurusan Fisika FMIPA Universitas Negeri Medan \\ Kyudess3112@gmail.com
}

\begin{abstract}
ABSTRAK
Penelitian ini bertujuan untuk mengetahui perbedaan hasil belajar siswa akibat pengaruh model pembelajaran inquiry training pada materi Listrik Dinamis kelas X SMA Swasta Katolik Budi Murni 2 Medan. Jenis penelitian yang digunakan adalah quasi eksperimen. Populasi dalam penelitian adalah seluruh siswa kelas X SMA Swasta Katolik Budi Murni 2 Medan. Pengambilan sampel dilakukan dengan cara cluster random sampling dan terpilih dua kelas, dimana kelas pertama dengan 39 siswa sebagai kelas eksperimen diterapkan model inquiry training dan kelas kedua dengan 41 siswa sebagai kelas kontrol diterapkan pembelajaran konvensional. Dari hasil penelitian diperoleh hasil belajar untuk kelas eksperimen lebih tinggi dari kelas kontrol. Sehingga dapat disimpulkan bahwa ada perbedaan hasil belajar siswa akibat pengaruh model pembelajaran inquiry training pada materi Listrik Dinamis kelas X SMA Swasta Katolik Budi Murni 2 Medan.
\end{abstract}

Kata Kunci : model pembelajaran, inquiry training, hasil belajar

\begin{abstract}
The purpose of this research was to determine the difference of student's learn result because of effect of inquiry training model at dynamic electricity subject in class X SMA Swasta Katolik Budi Murni 2 Medan. The kind of this research is quasi experiment. The population of this research is all of class X in SMA Swasta Katolik Budi Murni 2 Medan. Sampling was done by cluster random sampling and two class was selected, for the first class with 39 students can be mentioned as the experiment class used inquiry training model dan the second class with 41 students can be mentioned as control class used conventional learning. From the research's result obtained that the learn result for experiment class was higher than control class. It means that there is difference of student'slearn result because of the effect of inquiry training model at dynamic electricity subject in class $X$ SMA Swasta Katolik Budi Murni 2 Medan.
\end{abstract}

Keywords : learning model, inquiry training, learn result

PENDAHULUAN Pendidikan adalah salah satu bentuk perwujudan kebudayaan manusia yang dinamis dan sarat perkembangan. Oleh karena itu, perubahan atau perkembangan pendidikan adalah hal yang seharusnya terjadi sejalan dengan perubahan budaya kehidupan. Perubahan dalam arti perbaikan pendidikan pada semua tingkat perlu terus menerus dilakukan sebagai antisipasi kepentingan masa depan.

Pendidikan yang mampu mendukung pembangunan di masa mendatang adalah pendidikan yang mampu mengembangkan potensi 
peserta didik, sehingga yang bersangkutan mampu menghadapi dan memecahkan problema kehidupan yang dihadapinya. Pendidikan harus menyentuh potensi nurani maupun potensi kompetensi peserta didik. Konsep pendidikan tersebut terasa semakin penting ketika seseorang harus memasuki kehidupan di masyarakat, karena yang bersangkutan harus mampu menerapkan apa yang dipelajari di sekolah untuk menghadapi problema yang dihadapi dalam kehidupan sehari - hari saat ini maupun yang akan datang.

Masalah utama dalam pendidikan dewasa ini adalah masih rendahnya daya serap peserta didik. Hal ini tampak dari rata - rata hasil belajar peserta didik yang senantiasa masih memprihatinkan. Prestasi ini tentunya merupakan hasil kondisi pembelajaran yang masih bersifat konvensional dan tidak menyentuh ranah dimensi didik itu sendiri, yaitu bagaimana sebenarnya belajar. dalam arti yang lebih substansial, bahwa proses pembelajaran hingga dewasa ini masih memberikan akses bagi anak didikuntuk berkembang secara mandiri melalui penemuan dalam proses berpikirnya.

Berdasarkan hasil analisis penelitian secara empiris, rendahnya hasil belajar peserta didik yang disebabkan dominannya proses pembelajaran konvensional. Guru lebih suka menerapkan pembelajaran ini karena tidak memerlukan alat dan bahan praktik, cukup menjelaskan konsep - konsep yang ada pada buku. Tidak dapat disangkal, bahwa konsep merupakan suatu hal yang sangat penting, namun bukan terletak pada konsep itu sendiri, tetapi terletak pada bagaimana konsep itu dipahami. Kenyataan di lapangan siswa hanya menghafal konsep dan kurang mampu menggunakan konsep tersebut jika menemui masalah dalam kehidupan nyata yang berhubungan dengan konsep yang dimiliki. Hal seperti ini juga terjadi pada pembelajaran sains termasuk dalam pembelajaran fisika di sekolah.

Ada banyak faktor yang menyebabkan hasil belajar siswa rendah, diantaranya kebiasaan siswa belajar hanya menerima informasi dari guru tanpa tahu apa makna informasi itu sehingga siswa merasa jenuh dalam belajar fisika, kurangnya minat untuk belajar fisika dimana hal ini terlihat ketika siswa sering mengeluh ketika akan belajar fisika, dan cara penyampaian guru dalam pembelajaran yang kurang menarik dimana guru lebih sering melakukan metode ceramah walaupun terkadang guru melakukan metode yang berbeda seperti demonstrasi dan metode diskusi. Hal ini mungkin disebabkan karena pengajaran fisika disajikan hanya berfokus untuk mengetahui konsep tanpa menghubungkan materi yang dipelajari dalam kehidupan sehari-hari.

Berdasarkan pemaparan masalahmasalah tersebut di atas, salah satu usaha yang dapat dilakukan oleh guru untuk memperbaikinya adalah dengan pemilihan metode dan model pembelajaran yang tepat yaitu pembelajaran yang dapat melibatkan siswa secara aktif sehingga siswa belajar dengan suasana yang menyenangkan, yaitu menggunakan model pembelajaran inquiry training. Model pembelajaran inquiry training adalah model yang melibatkan siswa secara aktif dalam pembelajaran dan bertujuan untuk melatih kemampuan siswa dalam meneliti, menjelaskan fenomena, dan memecahkan masalah ilmiah.

Model pembelajaran inquiry training dikembangkan oleh seorang tokoh bernama Suchman. Menurut Uno (2011) tujuan utama dari model inquiry training adalah membuat siswa menjalani suatu proses tentang bagaimana pengetahuan diciptakan. Untuk mencapai tujuan ini, siswa dihadapkan pada sesuatu (masalah) 
yang misterius, belum diketahui, tetapi menarik. Namun, perlu diingat bahwa masalah tersebut harus didasarkan pada suatu gagasan yang memang dapat ditemukan (discoverable ideas), bukan mengada - ada. Awalnya model pembelajaran ini digunakan untuk mengajarkan ilmu pengetahuan alam, namun selanjutnya dapat digunakan untuk semua mata pelajaran. Semua topik mata pelajaran dapat digunakan sebagai suatu situasi masalah yang dapat dilontarkan oleh guru untuk melatih siswa cara bersikap dan berperilaku ilmiah (Joyce,dkk :2011)

Model pembelajaran inquiry training telah diteliti oleh beberapa peneliti sebelumnya seperti : Waramita (2013) menerapkan model inquiry training dalam materi pokok Cahaya memperoleh hasil belajar dengan nilai rata - rata 66,11 dan hasil belajar siswa dengan menggunakan model pembelajaran konvensionalrata-rata sebesar 57,74

dan Sirait (2012) yang menerapkan model pembelajaran inquiry training dalam materi pokok Gerak Lurus memperoleh hasil belajar dengan nilai rata - rata 74,63 dan hasil belajar siswa dengan menggunakan model pembelajaran konvensional rata-rata sebesar 68,13.

Berdasarkan uraian di atas maka peneliti melakukan penelitian untuk mengetahui perbedaan hasil belajar siswa akibat pengaruh akibat model pembelajaran inquiry training pada materi pokok listrik dinamis di SMA Swasta Katolik Budi Murni 2 Medan T.P 2014/2015

\section{METODE PENELITIAN}

Penelitian ini akan dilaksanakan di SMA Swasta Katolik Budi Murni 2 Medan pada semester genap T.P 2014/2015.

Populasi dalam penelitian ini adalah seluruh siswa kelas X SMA Swasta Katolik Budi Murni 2 Medan yang terdiri atas 6 kelas. Pengambilan sampel dilakukan secara cluster random sampling. Dua kelas yang dijadikan sampel untuk diperlakukan secara berbeda, yaitu kelas X-4 sebagai kelas eksperimen dengan 39 siswa dan kelas X-3 dengan 41 sebagai kelas kontrol.

Jenis penelitian ini adalah penelitian quasi eksperimen. Desain penelitian yang digunakan yaitu control group pre-test-post-test design( Arikunto : 2010) seperti yang tersaji pada Tabel 1

Tabel 1. Desain Penelitian

\begin{tabular}{cccc}
\hline \multicolumn{1}{c}{ Kelas } & $\begin{array}{c}\mathrm{Pre}^{-} \\
\text {test }\end{array}$ & $\begin{array}{c}\text { Perlakua } \\
\mathrm{n}\end{array}$ & $\begin{array}{c}\text { Postt } \\
\text { es }\end{array}$ \\
\hline Eksperimen & $\mathrm{O}_{1}$ & $\mathrm{X}_{1}$ & $\mathrm{O}_{2}$ \\
Kontrol & $\mathrm{O}_{1}$ & $\mathrm{X}_{2}$ & $\mathrm{O}_{2}$ \\
\hline
\end{tabular}

Keterangan:

$\mathrm{X}_{1}=$ Model pembelajaran Inquiry Training di kelas eksperimen

$\mathrm{X}_{2}=$ Pembelajaran konvensional $\mathrm{di}$ kelas kontrol

$\mathrm{O}_{1}=$ Pretes pada kelas eksperimen dan kelas kontrol

$\mathrm{O}_{2}=$ Postes pada kelas eksperimen dan kelas kontrol

Instrumen penelitian ini adalah tes hasil belajar fisika pada materi pokok Listrik Dinamis. Tes yang digunakan untuk memperoleh data hasil belajar siswa sebelum dan sesudah pembelajaran model inquiry training berupa tes uraian yang terdiri dari 10 item. Penilaian hasil belajar digunakan pedoman penskoran yang dimodifikasi dari Marzano (2006) seperti ditunjukkan pada Tabel 2pedoman penskoran hasil belajar

Tabel 2. Tabel Pedoman Penskoran Hasil Belajar

\begin{tabular}{rlc}
\hline No & \multicolumn{1}{c}{$\begin{array}{c}\text { Kriteria Jawaban terhadap } \\
\text { Soal }\end{array}$} & Skor \\
\hline 1 & $\begin{array}{l}\text { Tidak ada jawaban / } \\
\text { Menjawab tidak sesuai } \\
\text { pertanyaan /Tidak ada yang } \\
\text { benar }\end{array}$ & 0 \\
\hline
\end{tabular}


2 Jawaban hamper tidak mirip/ Sesuai dengan pertanyaan, 1 atau dengan masalah

3 Ada beberapa jawaban ynag mirip / Sesuai dengan pertanyaan, persoalan atau masalah tapi hubungannya tidak jelas

4 Jawaban mirip atau sesuai dengan pertanyaan, persoalan atau dengan masalah tetapi kurang lengkap

5 Jawaban sesuai dengan pertanyaan, persoalan atau masalah secara lengkap

Uji validitas yang digunakan dalam penelitian ini yaitu validitas isi kepada tiga orang ahli, yaitu dua orang dosen Fisika Unimed dan Guru Fisika.

Pengujian hipotesis menggunakan dua cara yaitu, uji hipotesis dua pihak untuk mengetahui kemampuan awal siswa pada kedua kelas.

Uji hipotesis satu pihak digunakan untuk mengetahui perbedaan dari suatu perlakuan yaitu model pembelajaran inquiry trainingterhadap hasil belajar siswa.

Hipotesis $\mathrm{H}_{0}$ diterima jika $t<t_{1-\alpha}$. Dan jika analisis data menunjukkan harga t yang lain, maka $\mathrm{H}_{0}$ ditolak dan terima $\mathrm{H}_{\mathrm{a}}$, berarti ada perbedaanhasil belajar fisika siswa pada kelas eksperimen (dengan menggunakan model pembelajaran inquiry training) dengan hasil belajar siswa pada kelas kontrol menggunakanpembelajaran konvensional ).

\section{HASIL DAN PEMBAHASAN Hasil Penelitian}

Hasil data nilai pretes kedua kelas ditunjukkan pada Gambar 1. (dengan

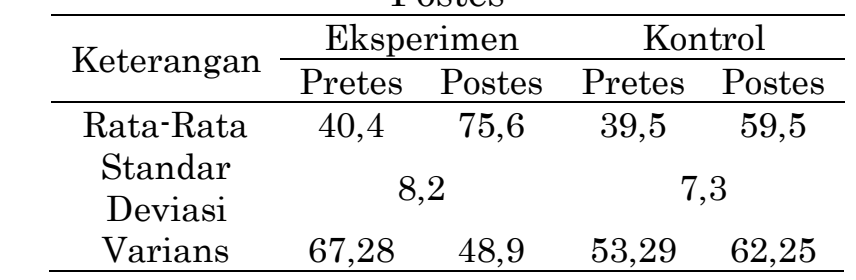

Tabel 3 menjelaskanhasil belajar siswa di kelas eksperimen yaitu 75,6 lebih tinggi dibanding hasil belajar kelas kontrol yaitu 59,5 sehingga dapat dikatakan bahwa ada perbedaan yang signifikan hasil belajar antara kelas eksperimen dan kelas kontrol.

Uji normalitas data dilakukan untuk mengetahui apakah data yang didapat berdistibusi normal sedangkan 
uji homogenitas dilakukan untuk mengetahui apakah data berasal dari populasi yang homogen. Hasil uji normalitas dan uji homogenitas disajikan masing - masing dalam Tabel 4 dan Tabel 5

Tabel 4. Hasil Uji Normalitas

\begin{tabular}{|c|c|c|c|c|}
\hline \multirow{2}{*}{ Keterangan } & \multicolumn{2}{|c|}{$\begin{array}{c}\text { Kelas } \\
\text { Eksperimen } \\
\end{array}$} & \multicolumn{2}{|c|}{ Kelas Kontrol } \\
\hline & Pretes & Postes & Pretes & Postes \\
\hline LHitung & 0,1240 & 0,0803 & 0,0493 & 0,0412 \\
\hline $\mathrm{L}_{\text {Tabel }}$ & 0,1418 & 0,1418 & 0,1383 & 0,1383 \\
\hline Kesimpulan & Normal & Normal & Normal & Normal \\
\hline
\end{tabular}

Tabel 4 menjelaskan bahwa LHitung masing-masing data yang diperoleh lebih kecil dari $\mathrm{L}_{\text {Tabel }}$ dengan taraf signifikan $\alpha=0,05$. Dengan demikian dapat disimpulkan bahwa data pretes dan postes di kelas eksperimen dan kelas kontrol berdistribusi normal.

Tabel 5. Hasil Uji Homogenitas

\begin{tabular}{lcrcr}
\hline \multirow{2}{*}{ Nilai } & \multicolumn{2}{c}{ Pretes } & \multicolumn{2}{c}{ Postes } \\
\cline { 2 - 5 } & $\begin{array}{c}\text { Eksperi } \\
\text { men }\end{array}$ & $\begin{array}{c}\text { Kont } \\
\text { rol }\end{array}$ & $\begin{array}{c}\text { Eksperi } \\
\text { men }\end{array}$ & $\begin{array}{c}\text { Kont } \\
\text { rol }\end{array}$ \\
\hline Varians & 67,28 & 53,9 & 48,9 & 62,2 \\
FHitung & \multicolumn{2}{c}{1,24} & \multicolumn{2}{c}{1,27} \\
F Tabel $_{\text {Kesimp }}$ & \multicolumn{2}{c}{1,90} & \multicolumn{2}{c}{1,71} \\
ulan & Homogen & Homogen \\
\hline
\end{tabular}

Tabel 5menjelaskan bahwa nilai $\mathrm{F}_{\text {Hitung }}$ data pretes adalah 1,24 dengan $\mathrm{F}_{\text {Tabel }}$ data pretes 1,90 dan $\mathrm{F}_{\text {Hitung }}$ data postes adalah 1,27 dengan $\mathrm{F}_{\text {Tabel }}$ data postes adalah 1,71 pada taraf signifikan $a=0,05$. Sehingga nilai $F_{\text {Hitung }}$ pada data pretes dan postes memenuhi criteria pengujian $\mathrm{F}_{\text {Hitung }}<\mathrm{F}_{\text {Tabel }}$, maka varians sampel homogen. Dengan demikian dapat disimpulkan bahwa data pretes dan postes kelas eksperimen dan kontrol memiliki varians yang relatif sama (homogen). Hal ini menunjukkan data yang diperoleh memenuhi persyaratan uji homogenitas untuk keperluan pengujian hipotesis.

Uji hipotesis menggunakan uji $\mathrm{t}$ dua pihak digunakan untuk mengetahui kesamaan kemampuan awal siswa pada kedua kelompok sampel. Sedangkan uji hipotesis dua pihak dilakukan untuk mengetahui perbedaan dari suatu perlakuan yaitu model pembelajaran inquiry trainingterhadap hasil belajar siswa dan ditunjukkan pada Tabel 6

Tabel 6. Ringkasan perhitungan uji

\begin{tabular}{cccl}
\multicolumn{4}{c}{ hipotesis } \\
\hline $\begin{array}{c}\text { Uji } \\
\text { Hipotesis }\end{array}$ & thitung $_{\text {tabel }}$ & Kesimpulan \\
\hline $\begin{array}{c}\text { Uji Dua } \\
\text { Pihak }\end{array}$ & 0,489 & 1,991 & $\begin{array}{l}\text { Kemampuan } \\
\text { awal siswa } \\
\text { sama } \\
\end{array}$ \\
& & & $\begin{array}{l}\mathrm{H}_{\text {a diterima }} \\
\text { (ada } \\
\text { perbedaan } \\
\text { hasil belajar } \\
\text { siswa akibat } \\
\text { pengaruh } \\
\text { model } \\
\text { pembelajaran } \\
\text { inquiry } \\
\text { training) }\end{array}$ \\
Pji Satu & \multirow{2}{*}{6,24} & 1,66 & \\
& & &
\end{tabular}

Berdasarkan tabel 6 diperoleh bahwa untuk nilai pretes tHitung $<\mathrm{t}_{\text {Tabel }}$ yaitu $0,489<1,991$ maka $\mathrm{H}_{0}$ diterima sehingga dapat disimpulkan bahwa kemampuan awal siswa pada kelas eksperimen sama dengan kemampuan awal pada kelas kontrol. Untuk nilai postes thitung $>$ tTabel yaitu 6,24 $<1,66$ maka $\mathrm{H}_{\mathrm{a}}$ diterima. Hal ini dapat disimpulkan bahwa ada perbedaan hasil belajar siswa akibat pengaruh Model Pembelajaran inquiry training pada materi pokok Listrik Dinamis di kelas X SMA Swasta Katolik Budi Murni 2 Medan T.A 2014/2015.

\section{Pembahasan}

Hasil penelitian ini menunjukkan bahwa ada perbedaan hasil belajar siswa akibat pengaruh model pembelajaran inquiry trainingpada materi listrik dinamis SMA Swasta Katolik Budi Murni 2 Medan T.P 2014/2015. Perbedaan hasil belajar antar kedua kelas ini disebabkan karena adanya penerapan model 
inquiry training, dimana model ini memberikan kesempatan kepada setiap siswa untuk terlibat aktif dalam proses belajar mengajar dan bertujuan untuk melatih kemampuan siswa dalam meneliti, menjelaskan fenomena, dan memecahkan masalah ilmiahmembangun sendiri pengetahuannya melalui latihan latihan yang dilakukan dalam pembelajaran.

Hasil belajar kedua kelas dapat dilihat dalam data yang tersaji dalam tabel 3, dimana hasil postes kelas eksperimen jauh lebih tinggi dari hasil postes kelas kontrol.

Data yang tersaji dalam Tabel 4 Uji Normalitas data diketahui bahwa LHitung masing-masing data yang diperoleh lebih kecil dari $\mathrm{L}_{\text {Tabel }}$ dengan taraf signifikan $\alpha=0,05$ dan dapat disimpulkan bahwa data dari kedua kelas adalah berdistribusi normal. Sedangkan untuk homogenitas kedua kelas dapat terlihat dalam Tabel 5, dimana terlihat bahwa nilai $\mathrm{F}_{\text {Hitung }}$ data pretes adalah 1,24 dengan $\mathrm{F}_{\text {Tabel }}$ data pretes 1,90 dan $\mathrm{F}_{\text {Hitung }}$ data postes adalah 1,27 dengan $\mathrm{F}_{\text {Tabel }}$ data postes adalah 1,71. pada taraf signifikan $\alpha=$ 0,05 . Sehingga nilai $F_{\text {Hitung }}$ pada data pretes dan postes memenuhi kriteria pengujian $\mathrm{F}_{\text {Hitung }}<\mathrm{F}_{\text {Tabel }}$, maka varians sampel homogen. Dengan demikian dapat disimpulkan bahwa data pretes dan postes kelas eksperimen dan kontrol memiliki varians yang relatif sama (homogen). Hal ini menunjukkan data yang diperoleh memenuhi persyaratan uji homogenitas untuk keperluan pengujian hipotesis

Uji hipotesis dilakukan uji $t$ dengan dua cara yaitu uji t dua pihak yaitu untuk mengetahui apakah kedua kelas memiliki kemampuan awal yang sama. Sedangkan uji t satu pihak digunakan untuk mengetahui apakah terdapat perbedaan hasil belajar siswa akibat pengaruh model pembelajaran inquiry trainingpada materi pokok listrik dinamis.
Hasil uji hipotesis disajikan dalam tabel 6 dimana terlihat bahwa pada uji t dua pihak tHitung $<$ tTabel yaitu $0,489<$ 1,991 maka $\mathrm{H}_{0}$ diterima sehingga dapat disimpulkan bahwa kemampuan awal siswa pada kelas eksperimen sama dengan kemampuan awal pada kelas kontrol. Sementara hasil uji t satu pihak diketahui bahwa thitung $>$ tTabel yaitu $6,24<1,66$ maka $\mathrm{H}_{\mathrm{a}}$ diterima. $\mathrm{Hal}$ ini dapat disimpulkan bahwa ada perbedaan hasil belajar siswa akibat pengaruh Model Pembelajaran Inquiry Training pada materi pokok Listrik Dinamis di kelas X SMA Swasta Katolik Budi Murni 2 Medan T.A 2014/2015.

Hasil penelitian ini sejalan dengan penelitian terdahulu yang diteliti oleh Waramita (2013) yang menyatakan menyatakan bahwa nilai rata - rata postes kelas eksperimen lebih tinggi daripada nilai rata - rata kelas kontrol. Selain itu juga hasil peneletian ini juga sejalan dengan hasil penelitian Sirait (2012), yang mendapatkan nilai postes kelas eksperimen lebih tinggi daripada kelas kontrol.

Hasil belajar pada kelas eksperimen yang diajar dengan model pembelajaran inquiry traininglebih tinggi daripada hasil belajar pada kelas kontrol dengan pembelajaran konvensional. Hal ini disebabkan karena model pembelajaran inquiry trainingmemberi peluang yang sama kepada semua siswa, baik yang memiliki kemampuan rendah, sedang ataupun tinggi untuk berhasil. Oleh karena itu, semua siswa ditantang untuk dapat menemukan inti materi pembelajaran dengan bantuan bimbingan dari peneliti. Siswa dalam hal ini aktif dan antusias untuk bekerja sama dengan teman satu kelompok dalam menyelesaikan masalah. Siswa juga tertarik dan aktif saat berdiskusi dan mengeluarkan pendapat yang berbeda saat diadakan diskusi antar kelompok. 
Berdasarkan hasil belajar siswa, dari 10 instrumen hasil belajar yang digunakan siswa sulit mengerjakan soal yang banyak mengandung besaran dan satuan, hal ini disebabkan siswa cenderung malas dalam memahami besaran dan satuan.

Kendala yang dihadapi penulis dalam menerapkan model pembelajaran inquiry trainingyaitu sulitnya menguasai kelas karena siswa yang terlalu ribut dan khususnya ketika kerja kelompok berlangsung sehingga menghambat proses diskusi kelompok. Maka bagi peneliti selanjutnya sebaiknya dalam melaksanakan penelitian dengan model inquiry training ini dibantu oleh guru bidang studi fisika agar terbentuk kolaborasi antara peneliti dengan guru bidang studi terutama dalam membimbing praktikum siswa sehingga terciptanya pembelajaran yang efektif.

Selain itu terjadi pemoloran waktu karena siswa seringkali bercanda dengan teman yang lain dan mengakibatkan kegiatan eksperimen sedikit terganggu. Untuk mengatasi kendala tersebut, sebelum pelajaran dimulai peneliti sebaiknya memotivasi siswa terlebih dahulu tentang pentingnya materi yang akan dibahas sehingga siswa tidak boleh menyianyiakan waktu yang tersedia.

\section{KESIMPULAN DAN SARAN \\ Kesimpulan}

Dari hasil analisis data yang dilakukan dapat disimpulkan bahwa antara kedua kelas yang dijadikan sampel memiliki perbedaan hasil belajar yang signifikan. Dari hasil perhitungan uji hipotesis diketahui bahwa ada perbedaan hasil belajar siswa akibat pengaruh model pembelajaran Inquiry Training pada materi pokok listrik dinamis di kelas X SMA Swasta Katolik Budi Murni 2 Medan.

\section{Saran}

Kepada peneliti selanjutnya diharapkan agar mencoba meminta bantuan dan mengikut sertakan guru bidang studi fisika di sekolah tersebut untuk membimbing dan mengamati siswa selama melaksanakan kegiatan praktikum didalam berdiskusi kelompok.

\section{DAFTAR PUSTAKA}

Arikunto, S., (2010), Prosedur Penelitian Suatu Pendekatan Praktik, Rineka Cipta, Jakarta.

Joyce, B., dan Weil, M., (2011), Models of Teaching, Pustaka Pelajar, Yogyakarta.

Marzano,RJ.,(2006), Classroom Assessment \& Grading that Work, Association for Supervision dan Curriculum Development Alexandria, Virginia AS

Sirait, J. (2012), Pengaruh Model Pembelajaran Inquiry Training Terhadap Hasil Belajar Siswa Pada Materi Pokok Gerak Lurus Di Kelas $X$ Semester I SMA Negeri 1 Percut Sei Tuan T.P 2011/2012, Skripsi, FMIPA, Unimed, Medan.

Uno,H.,(2011),Model Pembelajaran, Bumi Aksara, Jakarta.

Waramita, (2013), Pengaruh Model Pembelajaran Inquiry Training dengan Menggunakan Alat Sederhana Terhadap Hasil belajar Siswa pada Materi Pokok Cahaya Kelas VIII Semester II SMP Negeri 3 Air Putih Kab. Batu Bara T.P2012/2013, Skripsi, FMIPA, Unimed, Medan 